\title{
PROPORTIONALITY, GENERAL PRINCIPLES OF LAW, AND INVESTOR-STATE ARBITRATION: A RESPONSE TO JOSÉ ALVAREZ
}

\author{
Alec Stone Sweet* and Giacinto della Cananea**
}

I. The Global Diffusion of Proportionality .... 916

A. Diffusion and Justification .............. 918

B. Agents of Diffusion ................... 923

II. The Argentina Cases: Arbitrating the

Necessity Defense . . . . . ................ 924

A. The Evisceration of the "Orrego Vicuña

Approach"....................... 926

B. Continental Casualty and Proportionality ..... 932

C. A Response to Alvarez .................. 934

III. Boundary Crossings and Due Process ........ 940

A. Developments in Due Process................ 944

1. France............................ 945

2. India ......................... 946

B. The European Union and the WTO ......... 948

C. ICSW Arbitration ........................ 951

Conclusion $\ldots \ldots \ldots \ldots \ldots \ldots \ldots \ldots \ldots \ldots \ldots \ldots \ldots \ldots \ldots \ldots$

Judicial lawmaking constitutes the primary mechanism for the progressive construction of international law today. International judges and arbitrators make law, as a by-product of their functions as dispute-resolvers, not least, through interpreting norms found in treaties and other recognized sources of law. ${ }^{1}$ They do so, increasingly, in dialogues with

* Leitner Professor of International Law, Politics, and International Studies, Yale Law School.

** Professor of Law, University of Rome - Tor Vergata; visiting professor, Yale Law School.

1. We see nothing controversial in this statement. International judges make law to the extent that their rulings alter or clarify the meaning (as regards content, scope, or application) of international legal norms (customary international law, a treaty, or a general principle of law) in ways that judges, lawyers, and other actors will credit has having some, at least soft, precedential effect. On the issue of judicial lawmaking, see generally Armin von Bogdandy \& Ingo Venzke, Beyond Dispute: International Judicial Institutions as Lawmakers, 12 GER. L.J. 979 (2011), available at http://www.ger 
judges across jurisdictional boundaries. In this contribution to the 2013 Symposium of the New York University Jourmal of International Law and Politics, we explore these themes, focusing in particular on how judges and arbitrators have developed general principles of law.

Our focus on general principles of law deserves some preliminary discussion. As all readers will know, "the general principles of law recognized by civilized nations," ${ }^{2}$ which we would amend to include recognition among judges in effective legal systems, comprises one of the sources of law that members of the International Court of Justice (ICJ), and by extension all other international judges, are under a duty to apply, when relevant to a dispute at bar. At the same time, there is no codified statement of the content of the general principles, and no authoritative, prescribed method for identifying and applying them. Historically, the most important principles materialized in national judicial decisions, as more or less self-evident propositions, beginning in the late nineteenth century in Europe. General principles are unwritten, doctrinal constructions, institutionalized as case

manlawjournal.com/pdfs/Vol12-No5/PDF_Vol_12_No_05_979-1004_Be yond\%20Disptue\%20Special_Bogdandy\%20\&\%20Venzke\%20FINAL.pdf (demonstrating that international judicial lawmaking is ubiquitous, important, and beyond dispute). For a discussion of precedent by various international courts by a former President of the International Court of Justice, see Gilbert Guillaume, The Use of Precedent by International Judges and Arbitrators, 2 J. INT'L Disp. Settlement 5, 23 (2011) (arguing that "recourse to precedent is a necessity" for litigants, judges, and arbitrators, as well as to provide a basis for judicial dialogues across jurisdictional boundaries).

2. Article 38 of the Statute of the International Court of Justice states that:

1. The Court, whose function is to decide in accordance with international law such disputes as are submitted to it, shall apply:

a. international conventions, whether general or particular, establishing rules expressly recognized by the contesting states; b. international custom, as evidence of a general practice accepted as law;

c. the general principles of law recognized by civilized nations; d. subject to the provisions of Article 59, judicial decisions and the teachings of the most highly qualified publicists of the various nations, as subsidiary means for the determination of rules of law.

Statute of the International Court of Justice art. 38(1), Apr. 14, 1986, 59 Stat. 1031. 
law. Generated in the course of dispute resolution, national judges subsequently apply them (typically) as inherent, takenfor-granted, constituent elements of their legal systems. From the point of view of the wider legal order, these principles, in effect, supplement the national constitution or important legislation. In some cases, the principles substitute for the absence of any basic text that would govern the work of the courts, the paradigmatic case being the development of the general principles by the French Supreme Administrative Court, the Conseil d'État, and diffusion of this method to other jurisdictions across Europe and globally. It is no exaggeration to say that much of European (and Latin American) public law has been constituted by the development of general principles.

When international judges develop general principles of law, they become architects of their own legal systems, in relation to other legal systems. In identifying and applying a new general principle to resolve a dispute, they necessarily make new law. But the law they make, it is asserted, already exists as a matter of law-to the extent that other judges in different systems have developed the same principle in ways that have made it both normal and legitimate for use by all judges. Not surprisingly, those who worry about the destabilizing effects of judicial lawmaking, and who believe that judges can effectively resolve disputes without becoming lawmakers, will find no comfort in a jurisprudence that justifies the emergence of new law with reference to prior episodes of judicial lawmaking undertaken elsewhere.

The development of general principles has catalyzed systemic transformation in a wide range of national and international judicial systems, not least because such principles are foundational norms. Consider how scholars have described their various functions. General principles, it is claimed, lay "down the essential elements of the legal order," express the "fundamental legal concepts and essential values of any legal system," 4 and legitimate "all or any of the more

3. Armin von Bogdandy, Doctrine of Principles 10 (N.Y.U. Sch. of Law Jean Monnet Ctr., Working Paper No. 9/03, 2003), available at http://www .jeanmonnetprogram.org/archive/papers/03/030901-01.pdf.

4. Meinhard Hilf \& Goetz Goettsche, The Relation of Economic and NonEconomic Principles in International Law, in INTERNATIONAL ECONOMIC 
specific [legal] rules in question." ${ }^{5}$ Judges use principles to facilitate and justify gap-filling, when norms and procedures are determined to be inadequate or incomplete. They have developed others, such as the proportionality principle, to provide an analytic procedure for reconciling opposed values and interests, or to resolve conflicts between two sets of norms. And virtually all general principles can be deployed to promote coherence and order in systems beset or threatened by fragmentation, as well as to help judges adjust the law dynamically in the face of external shocks or changing circumstances.

At this point in time, it is likely that judges on international courts need general principles more than do their peers on established national courts. In most international regimes, states have not provided a code of procedures, and they have left crucial treaty norms incomplete, expecting courts to complete them on an ongoing basis. In the realm of investor-state arbitration (ISA), arbitrators are expected to enforce vague, open-textured provisions to resolve transnational disputes. The most obvious example is the fair and equitable treatment (FET) standard, which is common to virtually all bilateral investment treaties (BITs), but which is simply stated but not defined further. Today, the FET standard is treated by many arbitrators as a repository of general principles, precisely because arbitrators have interpreted it broadly, in light of principles that are common to other legal systems. In any case, as we have noted, the general principles of law are an authoritative source of law for international judges and arbitrators, and treaty regimes ought to, or must, be interpreted against the background of such principles. How judges do so is the crucial empirical question, and how they ought to do so is the crucial normative question.

In this Article, we address these questions in three linked ways. In Part I, we provide an overview of the process through which the general principle of proportionality, which judges operationalize as a multi-stage series of tests, has diffused globally. Today, the most powerful courts in the world, at both

Governance and Non-Economic Concerns: New Challenges for the INTERNATIONAL Legal. Order 9-10 n.13 (Stefan Griller ed., 2003).

5. Neil MacCormick, Legal Reasoning and Legal TheORY 152 (1978). 
the national and international levels, use proportionality analysis (PA) to assess state claims to available derogations from constitutional or treaty obligations for measures that are "necessary" to achieve important public or state interests. ${ }^{6}$

In Part II, we examine how proportionality appeared in ISA, in the context of the so-called Argentina cases that have been arbitrated under the authority of the International Centre for Settlement of Investment Disputes (ICSID). Since 2005, a series of arbitral tribunals have been required to interpret a derogation clause, contained in Article XI of the U.S.-Argentina Bilateral Investment Treaty (Art. XI-BIT) which, Argentina claimed, exempted it from liability to investors during its massive economic meltdown (roughly 1999-2002). ${ }^{7}$ In 2008, the tribunal in Continental Casualty $v$. Argentin $^{8}$ deployed a method of interpreting Art. XI-BIT that was directly inspired by the jurisprudence of the Appellate Body of the World Trade Organization. The move has been controversial in some quarters. José Alvarez and his collaborators, in particular, have harshly criticized the Continental Casualty award as being indefensible legally. ${ }^{9}$ Alvarez's views on the Argentina cases are untenable and we reject them.

6. See generally Alec Stone Sweet \& Jud Mathews, Proportionality Balancing and Global Constitutionalism, 47 Colum. J. TRANSNAT'L L. 73 (2008) (discussing the global use of proportionality analysis).

7. In chronological order: CMS Transmission Co. v. Arg. Republic, ICSID Case No. ARB/01/8, Award, I 332 (May 12, 2005); LG\&E Energy Corp. v. Arg. Republic, ICSID Case No. Arb/02/1, Decision on Liability, I 202 (Oct. 3, 2006); Enron Corp., Ponderosa Assets, L.P. v. Arg. Republic, ICSID Case No. Arb/01/3, Award, I 322 (May 22, 2007); Sempra Energy Int'l v. Arg. Republic, ICSID Case No. Arb/02/16, Award, I 364 (Sept. 28, 2007); Cont'l Cas. Co. v. Arg. Republic, ICSID Case No. ARB/03/9, Award, I 58 (Sept. 5, 2008); El Paso Energy Int'l Company v. Arg. Republic, ICSID Case No. ARB/03/15, Award, I 50 (Oct. 31, 2011).

8. Cont'l Cas. Co., supra note 7, Il 192.

9. José E. Alvarez \& Katheryn Khamsi, The Argentina Crisis and Foreign Investors: A Glimpse into the Heart of the Intermational Investment Regime, in THE Yearbook on International. Investment Law and Policy 2008/2009 379, 441 n.332 (Karl P. Sauvant ed., 2009). See generally José E. Alvarez \& Tegan Brink, Revisiting the Necessity Defense: Continental Casualty v. Argentina, 9 Transnat'L Disp. Mgmt. 319 (2012), available at www.transnational-disputemanagement.com/article.asp?key=1828 (discussing the methodological problems with the decision and advocating alternative rules of interpretation). 
In Part III, we widen the scope of the inquiry to address the evolution of the general principles of law more generally. Certain fundamental principles of law, not least the maxim nemo judex in re propria, derive from understandings about the law that are shared by most, if not all, the legal systems of the world. These general principles are foundational, in that they help judges organize the internal morality of any legal system based on the rule of law. When international and supranational courts assess the validity of national rules and measures, they should and do refer to the wider world of principles. In a recent paper, Beware Boundary Crossings, ${ }^{10}$ Alvarez, after restating his objections to Continental Casualty, argues that legal systems should not borrow from one another, or evolve common principles, except in narrow circumstances. We reject this view as well. Most important, Alvarez's approach fails to explain actual judicial practice, as our brief survey of the evolution of due process requirements in a variety of national and international jurisdictions demonstrates.

\section{The Global Diffusion of Proportionality}

The principle of proportionality has become a centerpiece of the jurisprudence of the world's most powerful national and international courts. From Germany, PA spread to virtually every high court in Europe, to the supreme courts of Canada, Israel, and New Zealand, to the constitutional courts of South African and Colombia, and many others. ${ }^{11}$ It is now the unrivalled, best-practice standard for adjudicating constitutional rights that are "qualified" by limitation clauses that permit a state to burden the exercise of rights for important pub-

10. José Alvarez, Beware Boundary Crossings, in Boundarjes of Rights, Boundaries of State (Tsvi Kahana \& Anat Schnicov eds.) (forthcoming) [hereinafter Alvarez: Boundary Crossings], available at http://www.law.yale .edu/documents/pdf/sela/Bewareboundarycrossings_nofootnotes_\%282\% 29.pdf.

11. See Stone Sweet \& Mathews, supra note 6 (tracing the migration of proportionality from Germany to Canada, Israel, New Zealand, South Africa, and across Europe, and to the European Union, the ECHR, and the WTO). aharon Barak, Proportionality: Constitutional Rights and Their LimiTATIONS 175-210 (2012) (discussing the diffusion of proportionality from Germany to Canada, Ireland, the United Kingdom, New Zealand, and to national legal systems in Asia and Latin America, as well as to international regimes). 
lic purposes. Most rights found in modern constitutions (postWorld War II) and the international bill of rights are qualified; that is, very few rights are expressed in "absolute" terms. At the international level, the proportionality framework has been adapted for use by the courts of the European Union (EU), the European Convention on Human Rights (ECHR), and the World Trade Organization (WTO), in particular, to adjudicate treaty provisions that permit states to claim derogations from their treaty obligations in the pursuit of important policy interests. While judges have adapted PA in different ways in different systems, it has been recognized as the single most successful legal transplant of the past sixty years. ${ }^{12}$

PA is a multi-stage analytical procedure for resolving legal conflicts of a particular structure, most commonly disputes between (a) an individual or state holder of a right, or other legal entitlement, and (b) a state, which has taken measures in pursuit of an important governmental interest, but which nonetheless burden the right holder. PA is typically triggered once a claimant has made a prima facie rights claim; it then proceeds through a sequence of tests. A state measure that fails any one of these tests is outweighed by the right: The measure violates the proportionality principle, and the state loses. It is important to emphasize in advance that PA does not dictate correct legal answers to legal questions, since it does not tell judges how to weigh the various interests and values at play in any case. Instead, PA is a procedure that gives a stable structure to legal argumentation: how lawyers are to make claims and counterclaims and how judges are to justify their rulings.

The first stage of PA mandates inquiry into the "suitability" of the measure under review. The government must demonstrate that the relationship between the means chosen and the ends pursued is rational and appropriate, given a legitimate purpose recognized by the constitution or treaty. ${ }^{13}$ Governments rarely lose at this stage. The second step-"necessity"-embodies what Americans know as a "narrow tailoring"

12. Mattias Kumm, Constitutional Rights as Principles: On the Structure and Domain of Constitutional Justice, 2 INT'L J. CoNsT. L. 574, 595 (2004).

13. This mode of scrutiny is broadly akin to what Americans call "rational basis" review, although under PA, the appraisal of government motives and choice of means is more searching. Jud Mathews \& Alec Stone Sweet, All Things in Proportion?: American Rights Doctrine and the Problem of Balancing, 60 EMORY L.J. 101, 102-06 (2011). 
requirement. At the core of "necessity analysis" is a least-restrictive-means (LRM) test, through which the judge ensures that the measure under review does not curtail the right at stake more than is necessary for the government to achieve its declared purposes. For some courts, testing for necessity has the most bite. In practice, judges do not invalidate a measure simply because they can find-or litigants can invoke-one less restrictive alternative to that which is under review. Instead, most courts check to see that the government did not refuse one or more less restrictive alternatives that were reasonably available. The third step-balancing stricto sensu-is also known as "proportionality in the narrow sense." In this phase, the judge weighs, in light of the facts, the benefits of the act (already found to have been narrowly tailored) against the costs incurred by infringement of the right, in order to decide which side shall prevail. Judges who rely most heavily on this stage (notably, members of the German Federal Constitutional Court and the Israeli Supreme Court) emphasize that this final stage allows them to "complete" the analysis, in order to ensure that no factor of significance to either side has been overlooked. ${ }^{14}$

We now turn to how PA diffused as a general principle of global scope and importance.

\section{A. Diffusion and Justification}

The three major international courts that have adopted PA-the European Court of Justice (ECJ), the European Court of Human Rights (ECtHR), and the Appellate Body (AB) of the WTO-did so without explicit justification or citation to authority. We encounter the same silence when we look to the development of proportionality at the national level.

The proportionality principle emerged in Germany, first as a matter of legal philosophy in the late-eighteenth century; then as a judge-made, unwritten principle of administrative law in the late-nineteenth century; and as constitutional law in the 1950s. The German Federal Constitutional Court (GFCC) initially invoked elements of proportionality on a case-by-case

14. Dieter Grimm, Proportionality in Canadian and German Constitutional Jurisprudence, 57 U. TORONTO L.J. 383, 393-95 (2007); Stone Sweet \& Mathews, supra note 6 , at 106-08. 
basis, without citing to a source or giving a rationale for its application. As Dieter Grimm, a former Justice on that Court from 1987-99, writes: "The principle was introduced as if it could be taken for granted."15 In the next decade, the GFCC constitutionalized it. In 1963, the Court indicated that it would deploy PA in all cases in which rights were restricted; ${ }^{16}$ in 1965 , it announced that the principle "possesses constitutional status." 17 To this day, the Court has never explicated the source of proportionality, although its importance is now viewed as primordial. Indeed, in 1968, the GFCC declared proportionality to be a "transcendent standard for all state action," binding on all public authorities. PA has since developed as a kind of doctrinal operating system, a stable interface for managing the Court's interactions with policymakers (legislators and administrators) and the judiciary.

PA became a pan-European constitutional principle due to its adoption by the European courts. The ECJ developed proportionality as an unwritten, general principle of EU law, with no justification given. ${ }^{18}$ It was introduced-in particular the least-restrictive means test that is at the core of necessity analysis-to adjudicate what were, in the 1970s and 1980s, the most important provisions of the Treaty of Rome (1957), those concerning the free movement of goods. Culminating in the famous 1979 Cassis de Dijon decision, ${ }^{19}$ PA was then applied to the other basic freedoms (free movement of services, labor, and capital), and adapted to manage the expansive field of non-discrimination. By the end of the 1980 s, in Schraeder, the Court announced that "the principle of proportionality is one of the general principles of Community law. By virtue of that principle, measures ... are lawful provided that [they] are appropriate and necessary for meeting the objectives legitimately pursued by the legislation in question. Of course, when there is a choice between several appropriate measures, the least on-

15. Grimm, supra note 14 , at 385 .

16. Bundesverfassungsgericht [BVERFG] [Federal Constitutional Court] June 10, 1963, Entscheidungen des Bundesverfassungsgericht [BVERFGE] 16, 194 (201) (1963).

17. BVerfG Dec. 15, 1965, BVerfGE 19, 342 (348-49).

18. Stone Sweet \& Mathews, supra note 6, at 139-46.

19. Case $120 / 78$, Rewe-Zentral AG v. Bundesmonopolverwaltung für Branntwein (Cassis de Dijon), 1979 E.C.R. 649. 
erous measure must be used. . ."20 For their part, the Member States have expressly ratified these moves in various ways. In the most recent example, Article 52 of the Charter of Fundamental Rights of the European Union (which entered into force in 2009) states: "Subject to the principle of proportionality, limitations [on rights] may be made only if they are necessary and genuinely meet objectives of general interest recognized by the Union or the need to protect the rights and freedoms of others." National judges, too, must use PA when adjudicating disputes involving the Charter of Rights, or when they apply EU law in domains in which the ECJ deploys it.

The ECtHR has been an even more potent force for the spread of PA across Europe. ${ }^{21}$ Most Convention rights, like most rights found in national constitutions, are qualified by limitation clauses. In the standard formula, states may "interfere with" or "restrict" the "exercise" of a Convention right (including to privacy, family life, conscience and religion, expression, assembly, and association), but only when such interferences are "prescribed by law" and "are necessary in a democratic society in the interests of national security or public safety for the prevention of disorder or crime, for the protection of health or morals, or for the protection of the rights and freedoms of others." In the 1980s, the ECtHR made proportionality its standard approach to adjudicating qualified rights. By that time, the GFCC and the ECJ were routinely using PA, as ECHR officials well knew. In the decades that followed, PA gradually became a master tool for managing the evolution of the Convention system. Among other things, the ECtHR uses necessity analysis to determine how much discretion-the size of the "margin of appreciation"-states possess when they act under limitation clauses. The Court tends to raise the standard of protection when a sufficient number of states have withdrawn public interest justifications for restricting a right; that is, the margin of appreciation shrinks as state consensus on higher standards emerges. Diffusion of the principle across Europe was assured when, in a series of rulings

20. Case 265/87, Schraeder v. Hauptzollamt Gronau, 1989 E.C.R. 2263, 2269.

21. Stone Sweet \& Mathews, supra note 6, at 146-60. 
beginning in $1999,{ }^{22}$ the ECtHR insisted that national judges deploy PA when adjudicating qualified rights. Failure to do so, the Court has held, ${ }^{23}$ would constitute a breach of the right to an effective judicial remedy. ${ }^{24}$

Prior to its consolidation in European law, proportionality was native only to Germany and Switzerland. It has now been institutionalized, typically as a constitutional principle, in all forty-seven of the Contracting Parties to the ECHR. ${ }^{25}$ Thus, whereas many international lawyers may think of national orders as the wellspring of general principles, principles can also flow from treaty regimes to national courts.

In the international trade regime, PA first appeared in the pre-WTO era, in a 1989 ruling of a General Agreement on Tariffs and Trade (GATT) panel: U.S.-Section 337 of the Tariff Act of 1937.26 The Panel deployed a LRM test to reject the United States' claim for an exemption from certain GATT obligations under Article XX of the GATT, which contains a list of "General Exceptions" to the GATT. Measures that come under one of the headings listed in Article XX and meet the conditions that have been developed by panels and the $\mathrm{AB}$ are permitted. Permissible exceptions include measures "necessary" to: protect public morals, intellectual property, and the life and health of humans, animals, and plants; secure compliance with customs rules; to prevent "deceptive practices" in the marketplace; and to conserve "exhaustible natural resources." In the WTO, litigating Article XX has been the principal means of testing the limits of state competences to deal with negative externalities of trade and other policy problems unilaterally.

22. See e.g., Smith and Grady v. United Kingdom, 29 Eur. H.R. Rep. 493 (1999).

23. See Peck v. United Kingdom, 36 Eur. H.R. Rep. 41 (2003); Hirst v. United Kingdom, App. No. 74025/01, 42 Eur. Ct. H.R. 41 (2005).

24. "Everyone whose rights and freedoms as set forth in this Convention are violated shall have an effective remedy before a national authority." European Convention on Human Rights art. 13, Nov. 4, 1950, E.T.S. 5, 213 U.N.T.S. 221.

25. On the incorporation of the ECHR into national legal orders, see generally Alec Stone Sweet, A Cosmopolitan Legal Order: Constitutional Pluralism and Rights Adjudication in Europe, 1 J. Global Const. 53 (2012).

26. Report by the Panel, United States-Section 337 of the Tariff Act of 1930, L/6439-36S/345 (Nov. 7, 1989), GATT B.I.S.D. (36th Supp.) at 345 (1989). 
The leading $\mathrm{AB}$ ruling is Korea-Beef (2001), ${ }^{27}$ which laid down general guidelines for necessity analysis. The $A B$ stressed that such analysis must proceed on a case-by-case basis, through a "process of weighing and balancing a series of factors," including "the extent to which the measure contributes to the realization of the end pursued," and the impact of the measure on trade. The defendant State is likely to lose if a less trade restrictive, or more GATT-consistent, measure exists. That said, the application of the LRM test is conditioned by a constraint. To reject an Article XX defense, judges and the claimant State are expected to identify specific policy alternatives that were "reasonably available" to the defendant State. The AB further summarized and refined its approach to Article XX GATT in Brazil-Tyres (2007). ${ }^{28}$

Beyond Europe, high courts in common law systems have also fully embraced proportionality. The Canadian Supreme Court imported PA in the mid-1980s to adjudicate qualified rights in the 1982 Charter of Rights and Freedoms. While we know that the justices were influenced by German and ECtHR doctrine, the Supreme Court chose not to cite to any authority. ${ }^{29}$ It was not until the 1990 s, once PA had become a widespread feature of judicial review globally, that judges began to justify its adoption. In Israel, Justice Aharon Barak wrote a series of opinions extensively discussing the origins and diffusion of proportionality-as an international and constitutional principle-before the Supreme Court adopted PA as its standard. ${ }^{30}$ The South African Constitutional Court, which was established before the new South African Constitution had been drafted, adopted proportionality in 1995 after surveying its development in German, Canadian, and European law, and noted differences and similarities with the South Africa context. In the same case, the Court insisted that the drafters of the new South African Constitution give explicit expression to

27. Appellate Body Report, Korea-Measures Affecting Imports of Fresh, Chilled and Frozen Beef, WT/DS161/AB/R, WT/DS169/AB/R, DSR 2001:I, 5 (Dec. 11, 2000).

28. Appellate Body Report, Brazil-Measures Affecting Imports of Retreaded Tyres, II 141-44, WT/DS332/AB/R (Dec. 3, 2007). In this ruling, the $A B$ provides an overview of its approach as it has evolved since Korea-Beef.

29. Stone Sweet \& Mathews, supra note 6, at 113-25.

30. Id. at $132-38$. 
the principle, which they did in a general "necessity" clause that applies to limitation clauses in the Charter of Rights. ${ }^{31}$

\section{B. Agents of Diffusion}

Proportionality diffused to international regimes through the deliberate choices of specific, identifiable judges. Hans Kutscher and Pierre Pescatore brought PA to the EU in the 1970s. Kutscher had been a justice on the GFCC during its crucial foundational period (1955-69), before becoming a member of the ECJ in 1970. When Cassis de Dijon was decided, Kutscher was the ECJ's President. Pescatore, formerly a professor of trade law, sat on the ECJ from 1967 to 1985 . He then went on to chair the GATT Panel that decided U.S.-Section 337 of the Tariff Act of 1937 in 1989, which he used to import PA into GATT jurisprudence. The WTO-AB ruling in Korea-Beef (2001), which institutionalized PA as the dominant approach to Article XX of GATT, was written by Claus-Dieter Ehlermann, who was a member of the AB from 1995-2001, finishing as its chairman. Ehlermann, a German, had previously served as a senior official in the EU Commission from 1977-95, and was the Director-General of the Legal Service when Cassis de Dijon was decided. The main agent for the development of PA in the ECHR context was Jochen Frowein, a member of the European Commission on Human Rights from 1973-93, and its Vice President from 1981-93. ${ }^{32}$

31. S. Afr. Const., 1996, ch. $2, \S 36$. The limitation clause reads:

36. Limitation of rights

1. The rights in the Bill of Rights may be limited only in terms of law of general application to the extent that the limitation is reasonable and justifiable in an open and democratic society based on human dignity, equality and freedom, taking into account all relevant factors, including-

a) the nature of the right;

b) the importance of the purpose of the limitation;

c) the nature and extent of the limitation;

d) the relation between the limitation and its purpose; and

e) less restrictive means to achieve the purpose.

2. Except as provided in subsection (1) or in any other provision of the Constitution, no law may limit any right entrenched in the Bill of Rights.

32. As an academic, Frowein was also associated with the Max Planck Institute for Comparative and International Law, Heidelberg, including as its director. 
The ECJ, the ECtHR, and the WTO AB use PA-in particular, LRM testing - to adjudicate provisions that allow states to claim derogations from their obligations under the treaty's law, for measures that are "necessary" to achieve public policy purposes. ${ }^{33}$ Alvarez, it should be noted in advance, has nonetheless denied that necessity analysis is related to any general principle of law capable of being justifiably recognized by international judges. ${ }^{34}$ Nonetheless, what comes next should now seem familiar. As discussed in the next section, Giorgio Sacerdoti, President of the Tribunal in Continental Casualty, adapted the WTO AB's version of PA to assess Argentina's claim for derogation under Article XI of the U.S.-Argentina BIT. Sacerdoti had previously served as a member of the WTOAB.

\section{The Argentina Cases: Arbitrating the Necessity Defense}

The cases generated by the Argentina crisis of 1999-2002 have attracted more attention than any in ICSID's history. Their salience is due to sheer numbers, the high value of the compensation being claimed, and the spectacular context-an economic meltdown of cataclysmic proportions-that generated them. To add to the drama, for disputes brought under the U.S.-Argentina BIT, Article XI makes available to Argentina a derogation clause for measures deemed "necessary" to meet the crisis. Argentina has systematically pleaded Article $\mathrm{XI}$, and will presumably continue to do so, testing the ICSID regime's capacity to generate consistent outcomes absent a doctrine of stare decisis and appellate review for errors in law. Our focus is on how the various Tribunals and Ad Hoc Annulment Committees responded to the necessity defense, in the ten awards produced to date.

33. For an analysis of the different uses of PA in these systems, see Alec Stone Sweet \& Thomas Brunell, Trustee Courts and the Judicialization of International Regimes: The Politics of Majoritarian Activism in the European Convention on Human Rights, the European Union, and the World Trade Organization, 1 J.L. \& CT. 61, 78 (2013).

34. Alvarez: Boundary Crossings, supra note 10, at 41. See also Alvarez \& Khamsi, supra note 9 , at 440 (arguing that the "least restrictive alternative" rule is not connected to any principle of international law). 
The cases discussed here are based on the same facts, which can be briefly summarized. After overcoming military dictatorship (1973-85), Argentina sought both to democratize and to build a more open, market-based economy. In the early 1990s, it signed BITs, ratified the ICSID Convention, and privatized state-run companies and utilities, with foreign participation. To encourage investors, Argentina pegged its currency to the U.S. dollar, promised that capital could move freely in and out of the country, and gave investors rights to participate in decisions that would affect revenue streams. These arrangements unraveled during the 1999-2002 period, when the country experienced an exploding budget deficit, a balance of payments crisis, and mounting foreign debt. In 2001, Argentina made deep budget cuts and renegotiated its debt obligations (which did not stave off default). It eventually permitted a devalued peso to float on the markets, restricted withdrawals from bank accounts, and forced conversion of dollar deposits into pesos, so-called "Pesification." It would probably be impossible to unravel the precise causal relationships that connect these factors: (1) the onset and deepening of the economic crisis; (2) mounting political instability, and (3) the increasingly desperate steps the Argentine State adopted to regain control. Each of these processes fed into the other two, leading the situation to spiral out of control. These questions of fact and causation were among the most difficult arbitrators faced.

What is undeniable is that Argentina's response to the crisis destroyed the regulatory environment on which foreign investors had relied ex ante. Investors turned to ICSID claiming, among other things, that Argentina violated the "fair and equitable treatment standard" (FET). In the ICSID system, arbitrators have developed the FET as a multi-purpose principle comprised of a wealth of sub-principles, including: good faith; access to justice and due process; regulatory transparency; nonarbitrariness and reasonableness; and the legitimate expectations of both parties. ${ }^{35}$ The FET standard allows arbitrators to

35. See S.W. Shill, Fair and Equitable Treatment, the Rule of Law, and Comparative Public Law, in International. Investment Law and Comparative PubLIC LaW 151 (S.W. Schill ed., 2010); Cristoph Schreuer, Fair and Equitable Treatment in Arbitral Practice, $6 \mathrm{~J}$. WORLd INVESTMENT \& TRAdE 357 (2005); Kenneth Vandevelde, A Unified Theory of Fair and Equitable Treatment, 43 N.Y.U. J. INT'L L. \& Pol. 43, 47 (2010). 
consider a wider range of elements than would be plausible under the tests for expropriation or regulatory takings (indirect expropriation). The standard clause gives little guidance to interpreters. The U.S.-Argentina BIT states simply: "Investment shall at all times be accorded fair and equitable treatment." 36 There is little disagreement that Argentina's response to the crisis, but for Article XI BIT, would constitute a violation of the FET provision. The crucial disagreement concerns how to interpret and apply Article XI.

To date, ICSID tribunals have issued six awards on the merits of such claims: CMS (May 2005); LGEFE (October 2006); Enron (May 2007); Sempra (September 2007); Continental Casualty (September 2008); and El Paso (October 2011). ${ }^{37}$ Cumulatively, the tribunals ordered Argentina to pay nearly $\$ 650$ million plus interest in damages, on original requests totaling around $\$ 2$ billion. In addition, Ad Hoc Annulment Committees have rendered final decisions on four of the awards (the parties in Sempra withdrew from the process), while the El Paso annulment proceeding is now underway. Each of these Committees discussed at length the tribunals' various approaches to Argentina's necessity defense, with differing effects. Although the process has destroyed certain approaches to interpreting Article XI, important ambiguities remain, including the status of the proportionality method embraced by the Continental Casualty Tribunal.

\section{A. The Evisceration of the "Orrego Vicuna Approach"}

Article XI of the U.S.-Argentina BIT contains a derogation clause, a "non-precluded measures" provision which reads, in its entirety:

This Treaty shall not preclude the application by either party of measures necessary for the maintenance of public order, the fulfillment of its obligations with respect to the maintenance or restoration of interna-

36. Treaty Concerning the Reciprocal Encouragement and Protection of Investment, U.S.Arg., art. II, Nov. 14, 1991, S. TrEATY Doc. No. 103-02 [hereinafter U.S.-Argentina BIT].

37. CMS Transmission, supra note 7, III 354-56; LG\&E Energy Corp., supra note 7, II 202; Enron Corp., supra note 7, I 306; Sempra Energy, supra note 7, I 348; Cont'l Cas. Co., supra note 7, II 304; El Paso Energy, supra note 7 , I 50 . 
tional peace or security, or the protection of its own essential security interests. ${ }^{38}$

To anyone familiar with how proportionality is used by national and international judges, Article XI would appear to be an obvious candidate for the application of PA. It provides a "carve-out" exemption from BIT obligations for state acts "necessary" to achieve certain, specified state purposes. Further, no language in Article XI, or in any other provision of this BIT, would preclude the application of a LRM testing.

Under PA, arbitrators would first decide if the crisis was severe enough to fall under one of the headings that make the necessity defense available. As a matter of comparative law, the notion of "public order" is a broad concept, encompassing core public policy concerns that state officials, including national judges, are under a duty to protect. Yet even if the parties to the BIT meant "the maintenance of public order" to apply only to threats to public security, it would arguably apply to the Argentina crisis. December 2001 saw rioting in the streets, a run on the banks, hyper-inflation, and political turmoil (five presidents were appointed in a ten-day period beginning on December 20,2001), including threats of a military coup. By the end of 2002, one-quarter of all urban workers were unemployed, and a majority of the population lived under the official poverty line. Arguably, the situation also posed a threat to Argentina's "essential security interests." If the arbitrators found that at least one of these headings covered the crisis, then they would typically probe the means-ends nexus which is at the heart of proportionality: suitability (was the measure designed to meet the crisis?); and necessity (a LRM test-did the measure harm investors more than was necessary to meet the crisis?), which might also include other forms of balancing. Of course, if Argentina failed any of these tests, the defense would be rejected.

In the first four awards rendered, on privatized gas concessions, ICSID tribunals did not embrace proportionality. The CMS, Enron, and Sempra tribunals found that Argentina had breached its obligations under the BIT, including the FET standard, while rejecting Argentina's Article XI pleadings. These tribunals were all chaired by Francisco Orrego Vicuña, a

38. U.S.-Argentina BIT, supra note 36 , art. XI. 
Chilean professor of public international law, who took a similar approach to Article XI in each case.

The "Orrego Vicuña approach" looks to customary international law for interpretive guidance to the necessity defense, that is, it denies that Article XI BIT is an autonomous source of law, as lex specialis. Instead, Article XI is subsumed by the customary international law defense of necessity. There is wide agreement that the best available expression of that law is Article 25 of the 2001 Draft Articles on the Responsibility of States for Internationally Wrongful Acts, elaborated by the International Law Commission (ILC). ${ }^{39}$ Article 25 ILC reads:

1. Necessity may not be invoked by a State as a ground for precluding the wrongfulness of an act not in conformity with an international obligation of that State unless the act: (a) is the only way for the State to safeguard an essential interest against a grave and imminent peril; and (b) does not seriously impair an essential interest of the State or States towards which the obligation exists, or of the international community as a whole.

2. In any case, necessity may not be invoked by a State as a ground for precluding wrongfulness if: (a) the international obligation in question excludes the possibility of invoking necessity; or (b) the State has contributed to the situation of necessity. ${ }^{40}$

Article XI BIT and Article 25 ILC are differently formulated, in obvious ways. Article 25 is more restrictive: Necessity may be invoked to excuse an act that violates international law when it is the "only way" a state can "safeguard an essential interest" in the context of a "grave and imminent peril." Article XI BIT expressly permits state measures under headings that cover a broader range of contexts. Whereas Article 25 ILC imposes an "only way" test for necessity, Article XI BIT appears tailormade for a LRM test, at least to anyone versed in PA.

39. In all of the rulings discussed here, all of the parties and arbitrators agreed that Article 25 ILC was authoritative. For an overview of the necessity defense in customary international law, see Robert D. Sloane, On the Use and Abuse of Necessity in the Law of State Responsibility, 106 AM. J. INT'L L. 447 (2012).

40. Draft Articles on Responsibility of States for Internationally Wrongful Acts art. 25, 53 UN GAOR Supp. (No. 10), U.N. Doc. A/56/10 (2001). 
In light of Article 25 ILC, the tribunals chaired by Professor Orrego Vicuña rejected Argentina's necessity defense on three grounds. First, as the Enron and Sempra awards put it, the economic crisis did not involve an "essential interest of the State" in that the "the very existence of the State and its independence" was not threatened. ${ }^{41}$ In $C M S$, the Tribunal stressed that "the Argentine crisis was severe but did not result in total economic and social collapse," although the tribunal stated that it would take account of the situation in the damages phase. ${ }^{42}$ Second, the CMS Tribunal interpreted the "only means" requirement under Article 25 as fatal to the necessity plea, if any other means than those chosen were available to Argentina. Since the record showed that experts and others disagreed on what mix of measures Argentina could have taken, the means chosen could not qualify as the "only means." Third, the CMS Tribunal held that Argentina's efforts to mitigate the crisis had actually contributed to it.

Meanwhile, the $L G \mathcal{E} E$ Tribunal, which also found breaches of the FET standard, accepted the necessity defense under both Article XI BIT and Article 25 ILC, separately. As a result, the Tribunal excused Argentina of liability, but only for measures taken during a specific period of "crisis" (December 2001-April 2003). The outcome contrasts with the main tenets of the Orrego Vicuna approach. In CMS, the Tribunal had stated that "the plea of state of necessity may preclude the wrongfulness of an act, but it does not exclude the duty to compensate the owner of the right which had to be sacrificed," 43 a view echoed later in the Enron and Sempra awards. ${ }^{44}$ The level of damages assessed by the LGEFE Tribunal damages (\$57.4 million) was far below the compensation ordered by Orrego Vicuna tribunals. Finally, the Tribunal invoked proportionality, but only to indicate that Argentina had not violated the principle; ${ }^{45}$ the award otherwise shows no indication that the tribunal engaged in PA.

41. Enron Corp., supra note 7, I 306; Sempra Energy, supra note 7, I 348.

42. CMS Transmission, supra note 7, II $354-56$.

43. Id. I 388 . 394.

44. Enron Corp., supra note 7, I 345; Sempra Energy, supra note 7, I

45. LG\&E Energy Corp., supra note 7, I 195 (“. . the State has the right to adopt measures having a social or general welfare purpose. In such a case, 
The decisions of the Ad Hoc Annulment Committees in CMS, Sempra, and Enron eviscerated the Orrego Vicuña approach. ${ }^{46}$ Annulment Committees introduce a dose of hierarchy to the ICSID system, while not being empowered to annul awards on grounds of "errors-in-law." Despite this formal constraint, arbitrators on the Committees regularly address such errors that they detect in dicta, and some have annulled awards for faulty legal reasoning under other available headings: for "failure to state the reasons," or "manifest excess of powers."47 Although the CMS Annulment Committee chose not to annul the Tribunal's award, it devoted much of its decision to a pointed criticism of the Orrego Vicuña approach. Less modestly, the Annulment Committees in Enron and Sempra annulled the tribunals' awards, on the basis of deficiencies in the analysis of Article XI BIT.

The CMS Annulment Committee's decision is the most significant of the three. ICSID authorities took appointment to the CMS Committee seriously, selecting two members of the ICJ, including the President of that Court, as well as the President of the ILC. In its decision, the Committee stressed that it did not have the authority to act as an appellate court; in particular, it could not quash an award on the basis of "errors in

the measure must be accepted without any imposition of liability, except in cases where the State's action is obviously disproportionate to the need being addressed.").

46. CMS Transmission Co. v. Arg. Republic, ICSID Case No. ARB/01/8, Decision of the Ad Hoc Committee on the Application for Annulment (Sept. 25, 2007) [hereinafter CMS Transmission, Annulment Proceeding]; Sempra Energy Int'l v. Arg. Republic, ICSID Case No. Arb/02/16, Decision on the Argentine Republic's Request for Annulment of the Award (June 29, 2010) [hereinafter Sempra Energy, Annulment Proceeding]; Enron Corp., Ponderosa Assets, L.P. v. Arg. Republic, ICSID Case No. Arb/01/3, Decision on the Application for Annulment of the Argentine Republic (July 30, 2010) [hereinafter Enron Corp., Annulment Proceeding]; Cont'l Cas. Co. v. Arg. Republic, ICSID Case No. ARB/03/9, Decision on the Application for Partial Annulment of Continental Casualty Company and the Application for Partial Annulment of the Argentine Republic (Sept. 16, 2011) [hereinafter Cont'l Cas. Co., Annulment Proceeding].

47. See, e.g., Patrick Mitchell v. Democratic Republic of the Congo, ICSID Case No. ARB/99/7, Decision on the Application for the Annulment of the Award, I 4 (Nov. 1, 2006). See also Benjamin M. Aronson, A New Framework for ICSID Annulment Jurisprudence: Rethinking the 'Three Generations', 6 VIENNA J. ON INT'L CoNST. L. 3 (2012) (discussing important developments in this area). 
law," no matter how serious. It then painstakingly detailed the "manifest" errors of interpretation committed by the CMS tribunal, the most important being the conflation of Article XI BIT and Article 25 ILC. The CMS tribunal should have analyzed pleadings under the two norms separately, the Committee stressed, as they are meant to function differently. The customary international law of necessity makes available to a state a defense for a breach of international law, once a breach has been found. In contrast, a plea under Article XI of the BIT, if accepted, precludes a finding of breach of the BIT in the first place. In extraordinary dicta, the Committee went on to state:

[The] errors made by the Tribunal could have had a decisive impact on the operative part of the Award. . . . In fact, it did not examine whether the conditions laid down by Article XI were fulfilled and whether, as a consequence, the measures taken by Argentina were capable of constituting, even prima facie, a breach of the BIT. If the Committee was acting as a court of appeal, it would have to reconsider the Award on this ground. ${ }^{48}$

Although the Committee's decision is not formally binding on future tribunals and annulment committees, it has exerted strong persuasive authority.

A second Annulment Committee annulled the Sempra award. Echoing the CMS Committee's views, the Sempra Committee noted that while "it may be appropriate to look to customary law as a guide to the interpretation of terms used in the BIT," "[i]t does not follow . . that [Article 25 ILC] establishes a "peremptory definition of necessity and the conditions for its operation." 49 The Committee then went on to hold that the Tribunal's failure to separately analyze and apply Article XI BIT constituted a "total" failure to apply the law, and thus a "manifest excess of powers" warranting annulment. ${ }^{50}$ According to the Annulment Committee, the Tribunal should have determined, first, whether Article XI BIT (the "primary" law governing the issue) covered the measures under review; only if Article XI did not apply should the Tribunal have moved to consider if breaches of the BIT were excused under

48. CMS Transmission, Annulment Proceeding, supra note 46, II 135.

49. Sempra Energy, Annulment Proceeding, supra note 46, II 197.

50. Id. II 213-14. 
customary international law (the secondary law governing). From this perspective, it appeared that the Tribunal had proceeded as if Article 25 ILC simply "trumped" Article XI BIT. ${ }^{51}$

A third Annulment Committee took a different tack, annulling the Enron award, focusing on the Tribunal's deployment of an "only means" test. Among other problems, the Committee found that the Tribunal had failed to give reasons for how it applied the "only way" requirement of Article 25 ILC. The Committee noted that necessity analysis under Article 25 could also imply a LRM test, or an assessment of the effectiveness of the state measure under review in light of its harm to investors, both congruent with PA. ${ }^{52}$ The Tribunal had apparently relied solely on the expertise of an economist to justify its rejection of Argentina's defense, without sufficiently considering the legal niceties of the law of necessity. The Committee expressly refused to indicate whether it agreed with the Tribunal's conflation of Article XI BIT and the customary international law defense. It saw no point in doing so, in part, because it had found that the Tribunal's rejection of the necessity defense under both Article XI and Article 25 ILC were thoroughly "tainted by annullable error." 53

In sum, the annulment committees destroyed the Orrego Vicuña approach, expressing strong disagreement with core elements. ${ }^{54}$

\section{B. Continental Casualty and Proportionality}

In the fifth award, Continental Casualty $v$. Argentina, ${ }^{55}$ the Tribunal's President, Sacerdoti, gave PA pride of place. Continental Casualty, a provider of employment compensation insurance in Argentina, maintained a portfolio of low-risk capital investments in Argentine financial institutions. Much of the value of this portfolio was lost with pesification and the rescheduling of payments on certain debt instruments held by the company. The company asked for $\$ 114$ million in compensation. Citing to the CMS Annulment Committee's decision,

51. Id. II 214-19.

52. Enron Corp., Annulment Proceeding, supra note 46, II 369-71.

53. Id. I 405.

54. The LG\&E Energy annulment application was withdrawn by the parties.

55. Cont'l Cas. Co., supra note 7. 
the Tribunal focused on Argentina's necessity plea under Article XI BIT, relegating customary international law to virtual irrelevance. It then confronted the crucial issue left open by the CMS Annulment Committee. what methodology should arbitrators use when they assess an Article XI defense?

In response, Sacerdoti adopted the approach developed in the WTO to adjudicate the necessity defense under Article $\mathrm{XX}$ of the GATT. He justified the move in the following way:

Since the text of Art. XI derives from the parallel model clause of the U.S. Friendship, Commerce, and Navigation treaties and these treaties in turn reflect the formulation of Art. XX of GATT 1947, the Tribunal finds it more appropriate to refer to the GATT and WTO case law which has extensively dealt with the concept and requirements of necessity in the context of economic measures derogating to the obligations contained in GATT, rather than to refer to the requirement of necessity under customary international law. ${ }^{56}$

The award also notes that the investor had "referred to the case law" under Article XX GATT. ${ }^{57}$

The Tribunal found that the economic crisis fell within the coverage of Article XI, under both the "maintenance of public order" and "essential security interests" headings. It then recognized, ECtHR-style, that the state possessed, ex ante, "a significant margin of appreciation" in the determination of how to meet the crisis, thus setting the stage for necessity analysis. The Tribunal adopted the approach laid out by the WTO-AB, quoting Korea-Beef and Brazil-Tyres. The necessity of a measure would be determined through "a process of weighing and balancing of factors," including the relative importance of interests furthered by the challenged measures, the contribution of the measure to the realization of the ends pursued, and the restrictive impact of the measure on international exchange. The Tribunal then assessed the state measures under review with regard to a list of alternatives that, the claimant had argued, were just as effective and reasonably available, but which would have done less harm to the inves-

56. Id. I 192.

57. Id. I 192 n.292. 
tor. With one minor exception, the Tribunal rejected these arguments, finding that Article XI BIT indeed covered Argentina's measures. 58

The award survived annulment. The Annulment Committee agreed with the CMS Annulment Committee's views on the distinction between Article XI BIT and the customary international law defense of necessity. ${ }^{59}$ With regard to the Tribunal's use of PA, the Committee rejected the company's claims to the effect that the Tribunal had "erred in its analysis" of WTO jurisprudence. "The Tribunal was clearly not purporting to apply that body of law," the Committee held, "but merely took it into account as relevant to determining the correct interpretation and application of Article XI of the BIT." 60

The most recent award on the merits is El Paso. The Tribunal, citing to Continental Casualty, focused on Article XI BIT, treating Article 25 ILC as "secondary law" (to be applied "only" if Article XI is found not to apply). ${ }^{61}$ Contrary to the $L G \mathcal{E} E$ and Continental Casualty tribunals, the El Paso Tribunal rejected Argentina's necessity defense, on a finding that its measures had "contributed to the crisis to a substantial extent, so that Article XI cannot come to its rescue." 62 In an unusual dissent inserted into the award itself, arbitrator Brigitte Stern stated that she would have taken the position of Continental Casualty on the necessity of Argentina's measures. ${ }^{63}$

\section{A Response to Alvarez}

The series of awards and decisions just examined eviscerated the Orrego Vicuna approach, while leaving some questions open. We submit that the following issues have been

58. The Tribunal found a breach of the FET standard on only one relatively minor claim (awarding $\$ 2.8$ million plus interest); the Tribunal's acceptance of Argentina's plea of necessity under Article XI of the BIT meant rejecting the others.

59. Cont'l Cas. Co., Annulment Proceeding, supra note 46, II 127-28.

60. Id. I 133.

61. El Paso Energy Int'l Co. v. Arg. Republic, ICSID Case No. ARB/03/ 15, I 553 (Oct. 31, 2011). The Tribunal also agreed that "the protection offered by the BIT to the Claimant's investment is suspended to the extent that Article XI is applicable." Id. II 649.

62. Id. I 665; see also id. I 624 (finding that necessity cannot be invoked if the party has substantially contributed to it).

63. Id. II $666-70$. 
largely settled by the arbitral process: First, Article XI BIT is lex specialis; where it applies, the customary international law of necessity, as expressed by Article 25 ILC, is largely "superfluous." 64 Second, Article XI can cover measures that are necessary to respond to an economic crisis of the kind experienced by Argentina in the 1999-2002 period. Third, it is not appropriate to apply an "only means" test to assess the necessity of Argentine measures under Article XI BIT. Fourth, the successful invocation of the necessity defense renders "inapplicable" the BIT's "protections." 65 The process of arbitrating Article XI has produced an alternative to the "only means" test, namely, the LRM test deployed by the Tribunal in Continental Casualty. It remains to be seen, of course, whether that test, or PA more generally, will become the doctrinal standard for necessity analysis in future awards.

José Alvarez and his collaborators ${ }^{66}$ take opposed positions on each of these four issues. In a first paper, Alvarez and Khamsi seek to demonstrate that the CMS, Enron, and Sempra Tribunals got it right in virtually all important respects, and that the Annulment Committee in CMS got it wrong. ${ }^{67}$ Thus, they argue that Article XI is not lex specialis, or a primary rule, but rather "incorporates" implicitly Article $25 \mathrm{ILC}$, as well as the "only means" test. Further, they submit that the necessity defense, even when accepted, does not excuse the state's liability to pay compensation. ${ }^{68}$ In a follow-up paper, devoted to criticizing Continental Casualty, Alvarez and Brinks again aggressively advocate the basics of the Orrego Vicuña approach, bolstering it through analysis of the historical origins of Article XI BIT, if only from the American point of view. They sum up their view as follows: "Article XI was essentially an attempt to preserve existing customary defenses and not to derogate from

64. Cont'l Cas. Co., supra note 7, I 162; see also El Paso Energy, supra note 7, I 552 (quoting Continental Casualty).

65. Cont'l Cas. Co., supra note 7, I 164.

66. Alvarez \& Khamsi, supra note 9, at 387; Alvarez \& Brink, supra note 9 , at 321 .

67. Alvarez \& Khamsi, supra note 9 , at $427-40$.

68. Id. at 454 (" $[\mathrm{I}] \mathrm{t}$ is difficult to even conceive of an economic situation of such magnitude that would genuinely pose [the] kind of threat to a state [envisioned under Article 25 ILC] and that would also require preventing payment of compensation to a foreign investor."). 
them,"69 that is, the Annulment Committees all got the law wrong in important respects.

These are rear-guard efforts to defend defeated propositions. It is a blunt fact that none of the five Annulment Committees that have weighed in thus far provide any support for the view put forth by Alvarez and Khamski and Alvarez and Brinks. Indeed, the CMS Annulment Committee characterized the conflation of Article XI and Article 25 ILC as "a manifest error in law."70 The Sempra Annulment Committee put it this way: "It is apparent from this comparison that Article 25 does not offer a guide to interpretation of the terms used in Article $\mathrm{XI}$. The most that can be said is that certain words or expressions are the same or similar."71 Moreover, faulty necessity analysis-of exactly the same kind as that endorsed by Alvarez and Khamski and Alvarez and Brinks-led to annulment of the Enron and Sempra awards. Even if one were to accept these scholars' arguments as defensible, the present state of the jurisprudence on Article XI BIT renders them, at best, academic. We would assign more weight to the positions taken by the President of the ICJ, a second Justice of the ICJ, and the President of the ILC-the composition of the CMS Annulment Committee-than to those of Alvarez and his collaborators. Arbitrators with responsibilities to make the authoritative choices in law have done so as well.

In further support of these points, it has come to light ${ }^{72}$ that Orrego Vicuña has recently been dismissed from an ISA tribunal for lacking impartiality with regard to his views on the necessity defense, namely, that an "essential security" clause of the kind found in Article XI BIT "should be interpreted so as to conform to the 'state of necessity' test under customary international law." 73 The disqualification ${ }^{74}$ was decided by the President of the International Court of Justice, Peter Tonka.

69. Alvarez \& Brink, supra note $\mathbf{9}$, at 334 .

70. CMS Transmission, Annulment Proceeding, supra note 46, I 146.

71. Sempra Energy, Annulment Proceeding, supra note 46, II 199.

72. We learned of this development only after submitting our paper to this Journal.

73. Luke Eric Peterson, Francisco Orrego Vicuna is Disqualified from Sitting in India BIT Arbitration Due to Appearance of Having Fixed View as to Meaning of "Essential Security" Standard, IA RePorTer (Oct. 10, 2013), http://www.iare porter.com/articles/20131010/print. The disqualification decision was rendered on September 30, 2013, in the UNCITRAL arbitration CC/Devas and 
In the words of a commentator with access to the full decision, Tonka stressed that "Prof. Orrego Vicuna has stuck to this view through three arbitral awards, but also in an academic article defending this view in the aftermath of the partial or total annulment of the three arbitral awards in question [referring to CMS, Enron, and Sempra, discussed above]. . . Indeed, Judge Tomka laid particular weight upon Prof. Orrego Vicuña's 2011 academic article where he discloses that he has reviewed the reasoning of the various ICSID annulment committees, but hewed to the same view as earlier." 75 Judge Tonka's comments apply to Alvarez's defense of these same views in Beware Boundary Crossings as well.

We now turn to the attack on Continental Casualty. Alvarez and his collaborators argue that Sacerdoti did not give an adequate justification for importing PA into ISA, and Alvarez and Brinks go so far as to accuse Sacerdoti of indolence: "[T] he Tribunal simply reached for an off-the-shelf model presumably because it was familiar-at least to the President of that tribunal."76 Sacerdoti, recall, after noting parallels between Article XI BIT and Article XX GATT, had considered it more appropriate to look to established doctrine in international economic law, than to force Article XI BIT into customary law.

The Tribunal could have taken another route. By the time the award in Continental Casualty was rendered, the proportionality principle had been recognized as an unwritten general principle of law by many of the world's most powerful national and international courts. Indeed, PA had become the unrivalled, best practice procedure for adjudicating derogation clauses found in constitutions and many treaties. Judges have, in effect, read into derogation clauses a LRM test, and other types of balancing, in order to help them assess the necessity of state measures. As discussed in Part I, the spread of proportionality initially took place without explicit justification

others v. India. CC/Devas (Mauritius) Ltd., et al. v. India, UNCITRAL (Sept. $30,2013)$.

74. Orrego Vicuña was nominated by the investor-claimant. As of February 2014, two more challenges to Orrego Vicuña are pending (Repsol, S.A. and Repsol Butano, S.A. v. Argentine Republic, ICSID Case No. ARB/12/38; Burlington Resources, Inc. v. Republic of Ecuador (ICSID Case No. ARB/ 08/5)). See also Peterson, supra note 73.

75. Peterson, supra note 73.

76. Alvarez and Brinks, supra note 9 , at 356 . 
on the part of judges, including the diffusion of PA to the European Union, the ECtHR, and the WTO. The Continental Casualty award is actually a rare exception. Nonetheless, Sacerdoti could also have reinforced his position by appealing to general principles. First, general principles are a recognized source of international law (Article 38 of the Statute of the ICJ); second, under the Vienna Convention on the Law of Treaties (Art. $31(3)(c))$, judges are to take into account the "relevant rules of international law applicable in the relations between the parties" when they interpret treaties, and proportionality may well be a "relevant rule."

In Beware Boundary Crossings, Alvarez explicitly rejects this proposed justification, going so far as to deny that proportionality, with its distinctive necessity test, is a general principle of law at all. ${ }^{77}$ Alvarez and Khamsi, for their part, bluntly state that "the 'least restrictive alternative' rule is not connected to any principle of international law that is relevant to interpreting the U.S.-Argentina BIT." They are wrong: Proportionality, which includes a LRM test at the "necessity" stage, is a widelyrecognized general principle of law that judges in the most powerful international courts use to adjudicate derogation clauses. ${ }^{78}$ In addition, the position Alvarez and Khamsi take rests on a discredited assumption. "To the extent that we are correct in concluding that Article XI needs to be read in light of the customary international law defense of necessity and is not lex specialis," they write, "it is evident that there is no room for an alternative test of necessity, such as the least restrictive alternative." Again, the response is obvious: The arbitral process has determined that Article XI BIT is, in fact, lex specialis. Moreover, as the Enron Annulment Committee pointedly emphasized, it may even be defensible to read a LRM test into Article 25 ILC. ${ }^{79}$

In the follow-up to Alvarez and Khamsi, Alvarez and Brinks seek to demonstrate: (1) that Sacerdoti's summary treatment of the negotiating history of Article XI BIT is bad history; and (2) that (a long list of) structural differences between the U.S.-Argentina BIT and the GATT 1947 ought to preclude importing PA from the WTO to ISA. On the latter

77. Alvarez, Boundary Crossings, supra note 10, at 41-42.

78. Stone Sweet \& Mathews, supra note 6; BARAK, supra note 11.

79. Enron Corp., Annulment Proceeding, supra note 46, II $369-71$ 
point, Alvarez and Brinks dwell on the fact that Article XX GATT-but not Article XI BIT-contains an introductory clause (the "chapeau") which denies an exemption for state measures that have been "applied in a manner which would constitute a means of arbitrary or unjustifiable discrimination." The point misses the target entirely, as Sacerdoti himself has noted in a response to Alvarez and Brinks, which he buried in a footnote. ${ }^{80}$ In addition, we would emphasize that, in many contexts, PA has been developed as a stand-alone framework for assessing discriminatory measures and practices; indeed, the LRM test is at the core of the EU approach to nondiscrimination, one of the largest bodies of jurisprudence produced by any international court. In the arbitral context, PA would quite naturally accommodate examination of whether a state measure under review had been applied in an arbitrary or discriminatory manner to the investor-claimant, including under Article XI BIT.

Beyond stubborn reliance on the moribund Orrego Vicuña approach, Alvarez and Brinks are largely silent on the questions that ought to matter most in this debate: Did the PA approach to necessity used in Continental Casualty lead the Tribunal to generate an indefensible award? If so, what important interests or values did the Tribunal leave out of the analysis? Did the arbitrators err in how they weighed the contending interests? If so, in what sense were these omissions and errors due to the analytical procedure deployed? Instead, Alvarez and his collaborators continuously cast PA, in its WTO form, as a type of deference doctrine. In fact, of nineteen of the twenty-one instances in which states have pleaded necessity under Article XX GATT, the AB has rejected the defense. ${ }^{81}$ In any event, the Continental Casualty award engages in a far more

80. Sacerdoti's response conforms to the basics of the WTO-AB's case law on Article XX. See Giorgio Sacerdoti, BIT Protections and Economic Crises: Limits to Their Coverage, the Impact of Multilateral Financial Regulation and the Defence of Necessity, 28 ICSID Review 1, 32 n.120 (2013) ("[T]he answer [to Alvarez and Brinks] is that the definition of 'necessity' in WTO case law is not affected by the presence of the chapeau. The latter contains the separate requirement that the application of the exception be non-discriminatory and in good faith and is subject accordingly to a separate subsequent analysis in WTO case law ... ."). With respect to WTO law, Sacerdoti also references other strong rebuttals of the position taken by Alvarez and Brinks, and by Alvarez in Beware Boundary Crossings, arguments that we take as definitive. Id.

81. Stone Sweet \& Brunell, supra note 33, at 83. 
sophisticated analysis of Article XI than the awards that came earlier, not least, in basing it on a transparent procedure for assessing all factors of importance to the parties.

Finally, Alvarez and Brinks conclude with this extraordinary claim, as if it self-evidently applies to the proportionality principle:

The legitimacy of cross-regime borrowing may turn on whether arbitrators factor these structural concerns into their articulated reasons to borrow. . . . Analogies to the use of foreign law by national courts seem appropriate here. National judges who seek inspiration from foreign law expose themselves to charges of lack of principle or incompetence should they fail to consider, for example, the structural differences between civil and common law trials when extrapolating applicable rules of evidence from one system to another. ${ }^{82}$

Yet it is obvious that the proportionality principle would never have spread-from Germany to the European Union to the WTO; and from civil law systems (in Europe) to common law systems (Canada, Israel, and South Africa) - had judges been placed under these strictures. PA diffused to become a global standard because it works, providing important benefits to both judges and the legal system as a whole.

\section{Boundary Crossings and Due Process}

We now turn to a broader consideration of the evolution of general principles. We note in advance that, since seminal works on the topic produced in the 1950s, there has been little explicit theorizing, and no systematic empirical research, on the underlying issues raised here. We begin by briefly contrasting approaches to the development of general principles, and reject that of Alvarez in Beware Boundary Crossings, insofar as Alvarez purports to describe actual judicial practices. We then discuss the evolution of norms of due process, the largest corpus of judge-made general principles.

The classic approach to general principles, outlined in a seminal paper written by Bin Cheng in 1954, stresses that general principles are superior to the other sources of interna-

82. Alvarez and Brinks, supra note 9 , at 352 . 
tional law listed in Article 38 of the ICJ Statute, in that they (1) "furnish the juridical basis of treaties and customs and govern their interpretation and application," and (2) "are common" to at least some effective rule of law systems, both national and international. ${ }^{83}$ Prior to the entry into force of Article 38 of the ICJ, judges and arbitrators had already begun developing the general principles of law in innumerable cases, using a mix of functional and comparative analysis. They did so, just as ICSID arbitrators do today, ${ }^{84}$ in order to fill gaps in the law they are applying, or the state law that they are reviewing. Further, unlike "judicial decisions" and the "writings of learned publicists," the general principles are not defined as "subsidiary sources" of law under Article 38. Instead, they are an autonomous source of legal norms whose legitimacy as positive international law is simply not in question. At the same time, Article $38(1)(c)$ is itself incomplete, in that it does not indicate how general principles, left un-enumerated, are to be identified, let alone applied.

We, too, emphasize the gap-filling functions of general principles, but we do not invoke the phrase "gap-filling" in order to disguise the extensive lawmaking that judges and arbitrators actually generate when they "fill gaps" through general principles. An incremental but expansive jurisprudence of general principles has served to construct (and reconstruct) the normative foundations of a long list of legal systems. We also recognize that, compared to the international system of the $1950 \mathrm{~s}$, the legal world has been transformed. International courts and arbitral institutions have proliferated, and the domain of justiciable individual claims against states has mas-

83. Bin Cheng, General Principles of Law as Applied by International Tribunals 383 (1954); see also Rudolph Schlesinger, Research on the General Principles of Law Recognized by Civilized Nations, 61 AM. J. INT'L L. 734, 735 (1957) (discussing Cheng's approach to general principles).

84. Arbitrators have recognized, for example, fundamental rules of natural justice, including nemo judex in cause propria and audi alteram partem, as well as the principle of res judicata. See CHENG, supra note 83, at 52, 257 (referring to the Greece-Bulgaria Mixed Arbitral tribunal in the Arakas (the Georgios) Case (1927), which held that "it is necessary that a judicial procedure should be followed, in the course of which both parties are heard"); see also Amco Asia Corporation and others v. Republic of Indonesia, ICSID Case No. ARB/81/1, Award (Nov. 20, 1984) [hereinafter Amco]; Helnan International Hotels A/S v. Arab Republic of Egypt, ICSID Case No ARB/05/19, Award, II 30 (June 14, 2010). 
sively expanded. These two factors have increased the demand, on the part of all users of the system, for general principles. Put differently, international law can no longer be understood merely as state-to-state contracting. Perhaps most importantly, states have proved unwilling or unable to produce treaties that are relatively "complete" contracts that could potentially constrain judicial lawmaking. Instead, states routinely leave crucial terms undefined, an example being the FET standard in BITs, or the necessity clause in Article XI of the U.S.-Argentina BIT. Judges are thus all but required to develop general principles in order to resolve disputes effectively; yet, in doing so, judges render more "complete" the treaty law they apply. ${ }^{85}$ When sovereigns do not subsequently override this lawmaking, they at least indirectly legitimize it.

In contrast, Alvarez's Beware Boundary Crossings stresses state sovereignty and inter-state contracting, committing itself to two tightly linked arguments. The first is the argument from original intent: State purposes enshrined in a treaty (a BIT) operate as a strict constraint on dispute resolution (the exercise of arbitral authority) under that treaty. The second is the argument from design: Boundary crossings are only defensible in cases where there exists sufficient institutional "fit" between the source legal system (from which one imports the principle) and the target legal system (the new host for the principle). These arguments prepare the way for the next step: the claim that each BIT establishes its own legal system, a type of lex specialis that prevails on other sources, including the general principles of law. ${ }^{86}$ Just as BITs can be distinguished from one another, the specificities of the investment sector separate it from other branches of international law, such as those of human rights, environmental protection, even trade. The im-

85. Rudolf Dolzer \& Christoph Schreur, Principles of InternaTIONAL INVESTMENT LAW 18 (2d ed. 2012) (pointing out that "general principles in the sense of Article 38(1) have received increasing attention in recent practice ... especially in the case of lacunae in the text of treaties . . . .").

86. See Alvarez, Boundary Crossings, supra note 10, at 37 (contending that the first flaw of public law theories is to neglect that each treaty "reflects the preferences of those who design it"). See also the dissenting opinion of arbitrator El Mahdi, in Middle East Cement Shipping and Handling Co. S.A. v. Arab Republic of Egypt, ICSID Case No. ARB/99/6, Award, II 147 (Apr. 12, 2002) (in which the majority of the tribunal found that the state had disregarded due process rights to be afforded the investor). 
portance of comparative law is thus reduced to an exercise in cataloguing difference between systems at a descriptive level, as if to deny that judges in them face similar problems. From this perspective, arbitral lawmaking, especially through the development of general principles, is suspect or worse, in that it undermines (rather than facilitates and enhances the effectiveness of) the state-to-state contracting that undergirds justiciable treaty law.

Alvarez's claims are normative and prescriptive-elaborate wishful thinking-rather than accurate descriptions of what judges actually have done, and continue to do, when they develop general principles. As discussed, proportionalitywith LRM testing at its core-was developed in Germany as an unwritten, judge-made principle, before moving from Germany to the European Union to the ECHR to the WTO, as a general principle. The process violated both of Alvarez's arguments: from original intent, and from institutional fit. Each of these treaty-based regimes is lex specialis (as are BITs or other treaty-based regimes), but obvious differences did not inoculate these systems from the contagion of general principles. More broadly, inter-judicial dialogues on general principles are growing in intensity and importance. Adherents of Alvarez's approach may lament that fact, but they cannot explain it.

We now examine how procedural justice is ensured by courts and arbitral tribunals in the context of administrative action. As will become clear, judges have not been bound by originalism or the constraints of micro-institutional, comparative analysis. Instead, they have built the effectiveness and legitimacy of their respective legal systems through developing general principles. Most judges had little choice, since states and national officials rarely provide much guidance in that area. We will also briefly examine the evolution of due process in a non-Western state, not least because Alvarez, in other set of arguments, claims that scholarship and practice on matters of general principles are limited to considerations of Western liberal democracies. ${ }^{87}$ At the heart of due process is the idea that adjudication cannot be considered legitimate if it does

87. Alvarez, Boundary Crossings, supra note 10, at 11, 40-42. 
not prevent arbitrariness from the standpoint of the parties. ${ }^{88}$ Indeed, at this point in time, the rule of law requires that every participant in a court proceeding possess rights to due process. These rights, the product of case law, are enshrined as general principles.

\section{A. Developments in Due Process}

The development of due process is neither a history of bounded legal systems, nor of a strict positivism that would deny judges the authority to make law. Indeed, if originalism always held sway, and boundary crossings were prohibited, many of the taken-for-granted principles of law, including those that make up due process today, would not have emerged. In the United States, even those who proclaim their fidelity to originalist dogma-Justice Scalia, for examplehave acknowledged that the correct interpretation of the Due Process Clause of the Fifth Amendment to the U.S. Constitution involves a boundary crossing, the importation of the "old English Law" in this case. ${ }^{89}$ Regressing further, the roots of this old English law were also a transplant. In the famous Bagg's case, Sir Edward Coke, Chief Justice of the King's Bench, referred to procedures that were required "by the law of the land," precisely in order to introduce a new and original principle, the maxim audiatur et altera pars, in the context of the dismissal of a civil servant without permitting him to make his case. Although Coke referred to the Magna Carta, he relied much more on Seneca's Medea, to anchor the "new" principle to the rule of reason more generally. ${ }^{90}$

88. J. Roland Pennock, Introduction, in DUe Process, Nomos XVIII, at XVI (J. Roland Pennock \& John W. Chapman eds., 1977).

89. A Conversation Between U.S. Supreme Court Justices: Antonin Scalia and Stephen Breyer, 3 I-CON 519, 535 (2005) (Justice Scalia affirming "[I]f you have that philosophy, obviously foreign law is irrelevant with one exception: old English law-because phrases like 'due process' and the 'right to confrontation' were taken from English law, and were understood to mean what they meant there.").

90. James Bagg's Case (1615) 11 Co. Rep. 93 (King's Bench) [99a]. See 4 William Blackstone, Commentaries (1765, ch. 20) (referring to the maxim audiatur et altera pars as an indispensable requisite of justice); DAWN OLIVER, Common Values and the Public-Private Divide 45 (1999) (providing further remarks on the case). 
In fact, the history of due process, now entrenched as a fundamental requirement of justice, is one of judicial lawmaking, transplants, and unfaithfulness to the legal texts revered by originalists.

\section{France}

The doctrinal foundations of French administrative law are almost entirely the product of an ongoing jurisprudence of general principles. In the early twentieth century, it became obvious that the Conseil d'État, in the absence of a legislative code, was increasingly grounding its rulings on general principles. Nonetheless, the high administrative court did not admit that it was doing so until after the fall of the Vichy regime (1944).$^{91}$ At that point, it began to catalogue general principles formally. The two leading cases, Aramu and Dame Veuve Trompier-Gravier, ${ }^{92}$ concerned the right of the defense against administrative decisions taken by the executive. In both, existing rules did not impose a duty on the decision-making authority to inform the addressee of the measure that it would take. Nonetheless, in Dame Veuve Trompier-Gravier, the Conseil d'État declared that a measure that seriously and adversely affects the interests of the claimant could not "legally" be taken without providing her with an opportunity to contest it, which in turn required notice. The same doctrine was applied in Aramu. In this case, the Conseil d'État went even further, proclaiming that an act of the executive branch was illegal if it violated the "applicable general principles of law, even in the absence of a [legal] text." 93

To explain these and many other subsequent moves, commentators observed that, in contrast to the state of affairs in

91. See Réné Cassin, Introduction, Etudes et Documents du Conseil D'Etat 3 n.3 (1951); Maxime Letourneur, Les Princepes Generaux du Droit Dans la Jurisprudence du Conseil d'Etat, 5 ETUdes ET DOCUMENTS dU CoNSEIL D'EтAт 19, 19 (1951); Roland Drago, The General Principles of Law in the Jurisprudence of the French Conseil d'Etat, 11 AM. U. L. REv. 126, 126-27 (1962); see also L. Nevlle Brown \& John S. Bell, French Administrative Law 216-21 (5th ed. 1998) (discussing later developments).

92. Aramu, CE Ass., Oct. 26, 1945, Rec. Lebon 213; Dame Veuve Trompier-Gravier, CE Sect., May, 5 1944, Rec. Lebon 133.

93. Aramu, CE Ass., Oct. 26, 1945, Rec. Lebon 213. For further remarks, see BENOÎT JEANNEAU, Les principes généraux du droit dans la jurisprudence administrative 82 (1954). 
the Ancien Régime, French law prohibits any denial of justice. The Civil Code, after all, provides that "the judge who shall refuse to judge, on the pretext of the silence, the obscurity, or the adequacy of the law, may be prosecuted as one guilty of denial of justice." 94 Although the Civil Code is mainly directed at civil judges, the high administrative court claimed that the duty to provide justice applies "especially" to administrative judges, given that they are called upon to fill gaps continuously, given the absence of a comprehensive code..$^{95}$ Nonetheless, the Conseil d'État denied that it was, in fact, making law, asserting that "when the judge applies general principles, he interprets the presumed will of the legislator and does not create law." 96 While remnants of this fiction remain in France, no one would deny today that the general principles of law, many of which have been constitutionalized by the Constitutional Council (the French constitutional court), are unwritten, judge-made norms that trump administrative acts (in administrative proceedings) and can at times prevail against statutes (in constitutional proceedings).$^{97}$

\section{India}

Article 21 of the Indian Constitution states: "No person shall be deprived of his life or personal liberty except according to procedure established by law." ${ }^{88}$ By design, the Framers

94. See Jan Paulsson, Denial of Justice in International Law 12 (2005) (comparing French and Swiss legislative provisions).

95. Aramu, CE Ass., Oct. 26, 1945, Rec. Lebon 213 ("qu'il résulte de ces prescriptions, ainsi d'ailleurs que des principes généraux du droit applicables même en l'absence de texte, qu'une sanction ne peut à ce titre être prononcée légalement sans que l'intéressé ait été mis en mesure de présenter utilement sa defense").

96. Maxime Letourneur \& Roland Drago, The Rule of Law as Understood in France, 7 Ам. J. Coмp. L. 147, 149 (1958).

97. For an overview of the recent evolution in the rights protection function of the French Council of State, see generally Mitchel LASSER, Judicial Transformations: The Rights Revolution in the Courts of Europe (2009). See also Aubert Lefas, A Comparison of the Concept of Natural Justice in English Administrative Law with the Corresponding General Principles of Law and Rules of Procedure in French Administrative Law, 4 QUEEN's L.J. 197, 229 (1978) (pointing out the "striking similarities" between English and French principles of procedural justice); Pascale Idoux, La Contradiction en Droit Administratif Français, in Faculté de Droit de Université de Montpellier, Collection Thèses, Vol. 2 (2005).

98. India Const. art. 21. 
had expressly rejected including a provision akin to the Due Process Clause of the Fifth Amendment of the U.S. Constitution. They chose a more modest obligation: The administration is under a duty to follow legislative procedures whenever it impinges on fundamental rights. They did so, in part, for procedural reasons. The advocates of the due process clause argued that the best way to protect the principles of natural justice, as affirmed in English law, was to follow the practice of earlier colonies that had gained independence from the British Empire. Others objected, on the ground that to do so would unduly limit the powers of the legislative and executive branches of government (Justice Felix Frankfurter had warned as much, in consultations with an Indian expert who had traveled to Washington to meet him). ${ }^{99}$

In the Gupalan case, the Indian Supreme Court deferred to the Founders' intent, and to the literal meaning of Article 21, denying the petitioner, who was jailed under rules governing preventive detention, habeas protections beyond the "procedure established by law." 100 The Court subsequently reversed course in a 1967 ruling involving the involuntary retirement of a civil servant, on grounds that her date of birth had been incorrectly reported. ${ }^{101}$ The public authority making the decision neither disclosed its findings nor gave her an opportunity to respond. The seriousness of these procedural deficiencies led the High Court to grant a writ, which the Supreme Court confirmed on appeal, after distinguishing the case from the Gupalan precedent. The Court further held that, because administrative decisions are often similar enough to judicial proceedings, they must "be made consistently with the rules of natural justice." 102

The reconstruction of Article 21 was consolidated ten years later, in Maneka Gandhi. ${ }^{103}$ That case involved a govern-

99. Manoj Mate, The Origins of Due Process in India: The Role of Borrowing in Personal Liberty and Preventive Detention Cases, 28 BERKELEY J. INT'L L. 216, 220-21 (2010).

100. A.K. Gopalan v. The State of Madras, (1950) S.C.R. 88 (India).

101. State Of Orissa v. Dr. (Miss) Binapani Dei \& Ors., (1967) 2 S.C.R. 625 (India).

102. A.K. Gopalan v. The State Of Madras, (1950) S.C.R. 88, 279 (India).

103. Maneka Gandhi v. Union Of India, (1978) 2 S.C.R. 621 (India). For a retrospective, see Mangal Chandra JaIn Kagzi, The Indian Administrative LAw 133 (5th ed. 1991). 
ment order to deprive a citizen of his passport, and therefore his right to travel. Among other things, the government argued that the right claimed by the individual was trumped by the superior, collective interest being protected by the public authority, namely ensuring that public order is respected and, thus, the security of all is also respected. The Supreme Court delved deeply into the government's claims, before rejecting them. The Court insisted that the claimant should have been granted a better opportunity to make his case, that the government had not given a "good enough reason .. . . for impounding [his] passport," and that "the public interest [could] be better served in some other manner."104 The conception of procedural fairness adopted by the Court goes well beyond the "procedure established by law," even pointing to proportionality. For Judge Bhagwati, evaluating the significance of the ruling retrospectively, it is never enough that a statute authorizes an interference with personal liberty; instead, it "should prescribe a procedure for so doing and such procedure must be reasonable, fair and just."105

\section{B. The European Union and the WTO}

No less than national judges, international judges have little choice but to construct norms of procedural justice through a jurisprudence of general principles. States, after all, did not contract codes of procedure in the European Union, the ECtHR, or the WTO, leaving the details to be worked out by the courts themselves. In the European Union, until the 2009 Charter of Rights entered into force, the entire corpus of fundamental rights, including norms of due process, were generated by the ECJ as general principles (the Member States had not provided for individual rights under the Treaty of Rome). Similarly, the ECtHR is the master of its own procedures. Since the Convention has little to say about procedural justice, the Strasbourg Court has generated guarantees on its own. The state contracted Dispute Settlement Understanding of the WTO, too, does not lay down a code of procedures. In

104. Maneka Gandhi v. Union Of India, (1978) 2 S.C.R. 621, 625 (India).

105. P.N. Bhagwati, Forward, in A.N. Chaturvedi, Rights of Accused UNDER INDIAN CONSTITUTION 6 (1984). The book also argues that due process, far from being an alien value, "was not unknown" in ancient India. Id. at 331 . 
consequence, the WTO-AB has developed procedures and due process as general principles. All three of these courts have gone beyond building due process guarantees into the procedures governing their activities, and they have also developed a host of general principles that apply to the governmental organs whose measures are under review.

The right to be heard in challenges to EU administrative actions is an excellent example of such lawmaking. As early as 1962, in Alvis $v$. Council, the ECJ announced that due process required a hearing prior to termination of public employment, holding that the requirement inhered in a "generally accepted principle of administrative law" in the legal systems of the Member States. ${ }^{106}$ A better known case, Transocean Marine Paint Association v. Commission (1974), ${ }^{107}$ expanded on the reasoning in Alvis. The claimant, a Dutch corporation, sued the Commission for refusing to renew certain exemptions to the Treaty of Rome's anti-trust rules. The ECJ, eschewing narrower pathways to the same result, went out of its way to generate an overarching general principle, that of audi alteram partem. The right to be heard, which the Court noted constituted a general principle of law common to the legal orders of the Member States, could henceforth be invoked by private parties, despite not being mentioned in any EU legal provision on the books. The ECJ, it is crucial to stress, confers on general principles the same rank as treaty law, and thus it is largely immune from override by the states, except through treaty revision. The right to be heard, along with other general principles generated by the Court under the rubric of "good and fair administration," is now codified as Article 41 of the Charter of Fundamental Rights of the EU. ${ }^{108}$

The most important WTO ruling on due process requirements borne by states under international trade law is the AB's ruling in Shrimp-Turtles $I I$ (1998). ${ }^{109}$ In that decision, the $\mathrm{AB}$

106. Case 33/62, Maurice Alvis v. Council of the EEC, 1962 E.C.R. 109.

107. Case $17 / 74$, Transocean Marine Paint Association v. Commission, 1974 E.C.R. 1063; see John A. Usher, General Principles of EC Law 73-77 (1998) (discussing Transocean).

108. Consolidated Version of the Treaty on European Union art. 6, May 9, 2008, 2008 O.J. (C 115) 13 (stating that the Charter has the "same legal value" as EU Treaties).

109. Three reports by WTO dispute resolution bodies are involved: I) Panel Report, United States-Import Prohibition of Certain Shrimp and 
agreed with U.S. claims to the effect that an interest in the protection of turtles, as an endangered species, justified a rule that shrimp harvesters employ a device enabling turtles to escape nets. It nonetheless found the process through which the United States had taken the measure had violated procedural norms, and was thus arbitrary and unjustifiable under the GATT. Not only had the United States not consulted with many countries whose industries would be affected prior to the rule's entry into force, but it had adopted the rule without observing basic notice and comment requirements. Further, the United States had failed to put into place a transparent and predictable certification procedure, or to ensure that reasons would be given for the rejection of applications for certification. The informality of these processes therefore failed to protect the rights of the shrimp-exporting nations and their individual exporters to "basic fairness and due process." 110

The AB's turn to due process requirements in Shrimp-Turtles II is not justified by any WTO legal instrument. There is no "audi alteram partem" in WTO law, and no instrument establishes a general principle of due process, binding on states, within the WTO. What, then, was the source of this new law? It may be that due process standards are part and parcel in any sound test of non-arbitrariness, to which all national measures potentially impinging on free trade must be subjected. It may be that the $A B$ decided to draw on an even broader principle, embodying requirements of procedural fairness that must be afforded to those whose rights in the economic sphere are endangered, or interfered with, by the government. It may be that the $\mathrm{AB}$ simply conceived such standards as being "inherent" in an adjudicatory system as such. Dogmatic ambiguity,

Shrimp Products, WT/DS58/R (May 15, 1998); II) Appellate Body Report, United States-Import Prohibition of Certain Shrimp and Shrimp Products, WT/ DS58/AB/R (Oct. 12, 1998); III) Appellate Body Report, United States-Import Prohibition of Certain Shrimp and Shrimp Products, WT/DS58/AB/RW (Oct.22, 2001). In the text we refer exclusively to the second [hereinafter Shrimp III.

110. Shrimp II, supra note 109, I 181. For further analysis, see Giacinto della Cananea, Beyond the State: The Europeanization and Globalization of Procedural Administrative Law, 9 Eur. Pub. L. 563, 573-76 (2003); Sabino Cassese, Global Standards for National Administrative Procedure, 68 LAw \& CoNTEMP. Probs. 109, 109-10 (2005) (demonstrating that a wide array of principles of due process has emerged in several international regimes). 
for better or worse, is a characteristic of lawmaking when it comes to general principles.

\section{ICSID Arbitration}

In the international investment field, nothing precludes the recognition of norms of due process of law as general principles under Article 38(1)(c) of the ICJ Statute. Arbitrators are, in fact, developing general principles of law, according to the basic gap-filling logic found in other systems. The FET standard, among other provisions common to most BITs, is a perfect "variable standard," 111 an incomplete norm that entrusts arbitrators with a considerable margin of discretion in considering issues of fact and law. Arbitrators have used their discretion to identify and apply due process guarantees that states owe investors. While they are not cataloguing general principles in the explicit manner (as, say, the ECJ does), Emmanuel Gaillard and Yas Banifatemi have, among others, argued that they could and should do so under the ICSID Convention. ${ }^{112}$ The first generation of ICSID annulment decisions, rendered by ad hoc committees in Klochner and Amco, strongly criticized tribunals for their failure to adequately derive principles of international law from comparative analysis of domestic law. ${ }^{113}$ Perhaps, in consequence, later tribunals have largely refrained from doing so explicitly.

The latter point made, it is undeniable that arbitral tribunals are developing standards of due process that would be recognizable to any comparative administrative lawyer as general principles of law. ${ }^{114}$ They are doing so in order to ensure

111. See Herbert L. Hart, The Concept of Law 131-32 (2d ed. 1994). Hart distinguishes between "the open texture of law," which means that there are standards that must be developed by courts in the light of "competing interests which vary in weight from case to case," while more determinate rules do not require from them a "fresh judgment from case to case." Id. at 125.

112. Emmanuel Gaillard \& Yas Banifatemi, The Meaning of 'and' in Article 42(1), Second Sentence, of the Washington Convention: The Role of International Law in the ICSID Choice of Law Process, 18 ICSID REv. 375, 411 (2003).

113. See Guillermo Aguilar Alvarez \& W. Michael Reisman, How Well Are Investment Awards Reasoned?, in THE REASONS REQUIREMENT IN INTERNATIONAL InVESTMENT ARbitration 1, 14-15 (Guillermo Aguilar Alvarez \& W. Michael Reisman eds., 2008) (describing the ad hoc committee's decisions).

114. These points are not controversial. See Thomas Wälde, The Specific $\mathrm{Na}$ ture of Investment Arbitration, in LES ASPECTS NOUVEAUX DU DROIT DES INVESTIS- 
that "justice" is rendered to investors. Arbitrators not only regularly refer to due process, they also give negative weight to facts in state treatment of investors that mirror the types of procedural dysfunctions and anomalies that are censurable in the major legal systems of the world. In some cases, arbitrators endorse the claimants' argument that the decisions taken by the State were based upon evidence not in the record, or upon evidence which the recipient had no opportunity at all to test by cross-examination (or that was even undisclosed). ${ }^{115}$ In other cases, they criticize governments for giving no reason at all. ${ }^{116}$

In any event, questions of procedural justice chronically arise in virtually every ISA case, as it did in one of the earliest: Amco. ${ }^{117}$ The dispute concerned the construction and opera-

SEMENTS INTERNATIONAUX - NEW ASPECTS OF INTERNATIONAL INVESTMENT LAW 100 (Philippe Kahn \& Thomas W Walde eds., 2007) (arguing that general principles comprise both international law and comparative law).

115. See Joseph Charles Lemire v. Ukraine, ICSID Case No. ARB/06/18, Award (Mar. 28, 2011). In Lemire, the claimant argued that Ukraine had violated the fair and equitable standard in the process of awarding broadcasting frequencies. The Tribunal upheld the claim that the process was unfair, being non-public and non-transparent. It added that the Ukrainian executive had acted without complying "with . . . procedures established in the law." Id. I 99. See also Kardassapoulos \& Fuchs v. Georgia, ICSID Case Nos. ARB $05 / 18 \& 07 / 15$, Award, I 395 (Mar. 3, 2010) (failure to provide notice and a hearing prior to expropriation of an oil and gas distribution enterprise). The Tribunal argued that legal procedures put in place by national rules or practices "must be of a nature to grant an affected investor a reasonable chance within a reasonable time to claim its legitimate rights and have its claims heard" if they are to conform to due process of law. Id. (quoting ADC v. Hungary, ICSID Case No. ARB/03/16, Award I 435 (Oct, 2, 2006)). The emergence of such elements had already been noted by the OECD. ORGANIZATION FOR Economic Co-operation and Development, Report on the Fair and EQuitable Treatment in INTERnational INVESTMENT LAW (2004).

116. Metalclad Corp. v. United Mexican States, ICSID Case No. ARB(AF)/ 97/1, Award, II 91 (Aug. 30, 2000) [hereinafter Metalclad]. More than a decade later, in Marion Unglaube v. Republic of Costa Rica (Unglaube), ICSID Case No. ARB/08/1, Award, I 246 (May 16, 2012), the Tribunal criticized actions or decisions that are "manifestly inconsistent, non-transparent [or] unreasonable (i.e., unrelated to some rational policy" (internal citation omitted).

117. Amco, supra note 84. For further analysis, see Michael W. Reisman, The Breakdown of the Control Mechanism in ICSW Arbitration, 4 DukE L. J. 739, 770-75 (1984) (criticizing the ad hoc annulment committees in Klochner and Amco for acting as if it were an appellate body with authority to correct errors in law). 
tion of a hotel in Indonesia, which had been halted when a national firm ran out of funds to complete it. Amco provided new investment for the project, in an agreement with a national development agency that would also permit it to manage the hotel. Once the hotel construction was substantially completed, a dispute arose between the parties. The agency, claiming that the investor had not fulfilled certain financial commitments, seized the hotel and replaced its management, aided by police and military forces. In its award, the Amco tribunal strongly criticized Indonesia, among other things, for granting to the company only a one-hour hearing, which it characterized as a violation of a fundamental principle of due process. ${ }^{18}$

Thirty years later, arbitrators are clearly pre-disposed to inquire, often intrusively, into the procedural law in place in states whose treatment of investors is under review. Since Amco, tribunals have elaborated and enforced three distinct standards: the intrinsic value of an orderly procedure; the maxim audi alteram partem; and, last but not least, the giving reasons requirement. ${ }^{119}$

One of the most cited and controversial arbitral awards, Metalclad, ${ }^{120}$ concerns all three. While the Tribunal also addressed related issues, the Tribunal put problems of procedural propriety quite neatly, under the FET standard heading. After attracting a U.S. waste disposal company to invest in Mexico, a local authority refused to permit the firm to operate a hazardous waste facility, in order to protect the environment and health. As the Tribunal noted, " $[t]$ he permit was denied at a meeting of the Municipal Town Council of which Metalclad received no notice, to which it received no invitation, and at

118. Amco, supra note 84, I 202. Interestingly, even those who criticise the award, such as M. Sornarajah, Controls of the Host State, in THE INTERNATIONAL LAW ON FOREIGN INVESTMENT 97, 165 (2d ed., 2004, recognize that providing due process is a "rule of prudence" and that state interference with foreign investors is now admissible only "provided due process standards are met." Id.

119. This section draws on Giacinto della Cananea, The Giving Reasons Requirement: A Global Standard for Administrative Decisions, in Global Standards For Public Authorities 19, 19-23 (Giacinto della Cananea \& Aldo Sandulli eds., 2012).

120. Metalclad, supra note 116 . The Tribunal's holding on the need of an "orderly process" has been referred to and shared by later awards, including CMS Transmission, supra note 7, at $\mathbb{1} 278$. 
which it was given no opportunity to appear."121 Pushing further, arbitrators also found that the municipality did not tailor any of its objections to the specifics of the company's proposed project, thus breaching the "giving reasons" requirement. Cases like Metalclad raise a point made by Martin Shapiro in his seminal study on the giving reasons requirement. To the extent to that the reviewing body (in our case, the arbitral tribunal) simply requests that reasons be given by the decisionmaker, the giving reasons requirement is a procedural constraint on power. When the reviewing body asks not just for reasons, but for good reasons, the requirement is converted into a substantive one. ${ }^{122}$ The development of general principles, such as the giving reasons requirement, reinforces ISA's claim to be a mode of transnational governance, not just a mechanism for dispute resolution.

\section{CONCLUSION}

The development of general principles of due process in public law, at both the national and international levels, is incompatible with the views of Alvarez and his collaborators. Judges have seen no use for either the argument from original intent, or the argument from design and institutional fit. They have instead conceived of due process as a fundamental requirement of fairness applying to any situation in which public authorities have balanced interests in ways that impinge on legal rights and entitlements. Because this situation is generic in public law-that is, every judge of public law decision-making will inevitably confront it-Alvarez's boundary constraints are largely irrelevant. Judges develop general principles because they need them. Filling lacunae in the applicable law helps judges do their jobs better, and developing due process helps to enhance their legitimacy when confronting controversial cases. It seems clear that judges, at least, do not doubt that they would be far worse off if they were to follow Alvarez's counsel.

121. Metalclad, supra note 116 , I 91.

122. Martin Shapiro, The Giving Reasons Requirement, 1992 U. CHI. LeGal F. $179,186$. 